\title{
Women and the Second World War
}

\author{
Sandra Trudgen Dawson \\ University of Maryland, Baltimore County \\ dawsons@umbc.edu
}

\begin{abstract}
The Second World War in Europe continues to captivate the attention of scholars and the general public even as the generation that lived through and fought in the war passes. The military and political histories of the war reveal the contribution of the men who fought as well as the men who led. Less attention has been directed to the experiences of women during the conflict who also served alongside the men in the military as nurses or auxiliaries, or as wives of spies. The articles in this special issue illustrate some of the hidden roles and choices women made during the conflict despite additional hurdles created by racism, and gender expectations.
\end{abstract}

\section{Keywords}

Second World War - women - wives - spies - African American wACs - Polish Army in the Soviet Union - Military nurses

As the eightieth anniversary of the outbreak of the Second World War in Europe approaches, the conflict continues to fascinate and engage historians. Belligerent nations targeted civilians and military personnel with evolving and destructive weaponry as Roger Chickering, Stig Förster and Bernd Greiner describe. ${ }^{1}$ The war was global, and its impact felt far from the Western, Eastern or Pacific fronts. The conflict disrupted all aspects of everyday life as the war machines of the belligerent nations demanded wartime labour, military service, rationing and sacrifice from citizens, colonies and imperial subjects as the

1 Roger Chickering, Stig Förster and Bernd Greiner, eds., A World at Total War: Global Conflict and the Politics of Destruction, 1937-1945 (Cambridge, 2005). 
work of David Edgerton, Ashley Jackson, Judith Byfield, Yasmin Khan, and others reveals. ${ }^{2}$ Indeed, this was a war that defied and complicated the definitions of battlefields and civilian environments. As Jeremy Noakes, Claudia Baldoli and others emphasise, aerial bombing in the conflict sought to eliminate states and peoples. ${ }^{3}$

New scholarship has moved beyond the traditional emphasis on political, military or diplomatic understandings of the war to more nuanced interpretations of the experiences of individuals and groups. This special issue of the International Journal of Military History and Historiography $(I J M H)$ builds on and advances previous research to offer significant new directions for the study of women's experiences during the Second World War.

Since the 196os, the role of women in the Second World War as war workers, victims and as auxiliaries to patriarchal militaries, has received scholarly attention. From the 1980s, and in response to Joan Scott's seminal article, scholars have used gender as a lens to interrogate wartime experiences. ${ }^{4}$ When applied to women's involvement in war, gender reveals the way femininity is subordinated to masculinity in a binary relationship that implicitly corresponds to the civilian/military divide. ${ }^{5}$ Studies of the Second World War reveal that while the civilian-military binary did not hold firm, neither did gender roles exclude women from armed combat as Fighters in the Shadows: A New History of the French Resistance (2015) suggests. ${ }^{6}$ Translated studies of Italian,

2 David Edgerton, Britain's War Machine: Weapons, Resources, and Experts in the Second World War (Oxford, 2011), and Ashley Jackson, The British Empire and the Second World War (New York, 2006), Judith Byfield, Carolyn Brown, Timothy Parsons, and Ahmad Alawad Sikainga, eds., Africa and World War II (Cambridge, 2015), Yasmin Khan, The Raj at War: A People's History of India's Second World War (London, 2015), and Mark Crowley and Sandra Trudgen Dawson, eds., Home Fronts: Britain and the Empire at War, 1939-45 (London, 2017).

3 Claudia Baldoli, ed., Bombing, States and Peoples in Western Europe 1940-1945 (London, 2011), and Jeremy Noakes, The Civilian in War: The Home Front in Europe, Japan and the UsA in World War II (Liverpool, 2000), Lizzie Collingham, The Taste of War: World War II and the Battle for Food (New York, 2011), Susan Grayzel, At Home and Under Fire: The Air Raid in Britain from the Great War to the Blitz (Cambridge, 2012), and Hannes Heer and Klaus Naumann, War of Extermination: The German Military in World War II (New York, 200o).

4 Joan Scott, "Gender: A Useful Category of Historical Analysis", The American Historical Review 91 (5) (1986): 1053-1075.

5 Margaret Higonnet and Patrice Higonnet, "The Double Helix", in Behind the Line: Gender and the Two World Wars, eds. Margaret Higonnet, Jene Jackson, Sonya Michel, and Margaret Weitz (New Haven, 1987), 31-50.

6 Robert Gildea, Fighters in the Shadows: A New History of the French Resistance (Cambridge, MA, 2015). 
Polish and Yugoslav female partisans by Ada Gobetti, Rachel Margolis and Jelena Batinić, also add to the significance of women's role in armed resistance. ${ }^{7}$

Other women, particularly in Western Europe, were skilled killers and engaged in espionage. Juliette Pattison argues that gender stereotypes were employed by the Special Operations Executive (SOE), which trained and used female spies because they were thought more able to avoid detection and 'pass' as civilians than men. ${ }^{8}$ Other studies have focused on the networks of women spies that provided a sense of community, for example, Sisterhood of Spies: The Women of the oss (2005), or the brave experiences of individuals in Heroines of SOE: Britain's Secret Women in France (2010) and Behind Enemy Lines: The True Story of a French Jewish Spy in Nazi Germany (2010). ${ }^{9}$ Less attention has been given to the partners of spies. In this special issue, Claire Hubbard-Hall and Adrian O'Sullivan study a largely overlooked topic in the Second World War the wives of spies. Taking an approach that moves the discussion of intelligence history away from operations and policy, Hubbard-Hall and O'Sullivan parse together fragments of information to give 'voice' to a neglected group and highlight some of the difficulties and danger they faced because of the work of their spouse. While this article looks specifically at wives of British and German spies, the voices of 'husbands' and same-sex partners remain potentially significant subjects for future research.

Women in the Second World War also engaged in militarized activities on the home front. Recent work by Corinna Peniston-Bird, Gerard DeGroot, Jutta Schwartzkopf and Joshua Goldstein further challenge the civilian/military binary by exploring the work and experiences of women in home defence and

7 Ada Gobetti, Partisan Diary: A Woman's Life in the Italian Resistance, trans. Jomarie Alano (Oxford, 2014), Rachel Margolis, A Partisan from Vilna, trans. F. Jackson Piotrow (Boston, MA, 2010), Jelena Batinić, Women and Yugoslav Partisans: A History of World War II Resistance (Cambridge, 2015).

8 Juliette Pattinson, Behind Enemy Lines: Gender, Passing and the Special Operations Executive in the Second World War (Manchester, 2007).

9 Elizabeth P. Mcintosh, Sisterhood of Spies: The Women of the oss (Annapolis, MD, 2009), Judith L. Pearson, The Wolves at the Door: The True Story of America's Greatest Female Spy (New York, 2014), Beryl Escott, Heroines of SOE: Britain's Secret Women in France (Stroud, 2010), Bernard O'Connor, SOE Heroines: The Special Operations Executive's French Section and Free French Women Agents (Stroud, 2018), Madeleine Masson, Christine: SOE Agent and Churchill's Favourite Spy: A Search for Christine Granville (London, 2005), and Marthe Cohn with Wendy Holden, Behind Enemy Lines: The True Story of a French Jewish Spy in Nazi Germany (New York, 2007). 
as members of anti-aircraft batteries. ${ }^{10}$ Studies of women in uniform from the early modern period to the present, as DeGroot, Peniston-Bird, Melissa Herbert, Nancy Goldman and others suggest, reveal the way notions of femininity continue to obstruct and resist the idea that women can or even should be soldiers, even as they are employed as warriors in conflict. ${ }^{11}$ Despite the resistance to accepting women as soldiers, members of the Women's Auxiliary Air Force (WAAF) as Tessa Stone maintains, constructed their own identities as uniquely integrated members of a military service. Thus, claims Stone, the evidence suggests that basing women's experiences purely on gender is inadequate. The military provided an alternative context within which women's identity and status operated. This is the subject of Sandra Bolzenius' article in this special issue. Bolzenius looks at the experiences of African Americans in the U.S. Women's Army Corps (WAC). The military, as Bolzenius claims, had long provided a means by which African American men could claim status as full citizens. For African American women, the wACs offered an opportunity to claim the same. Nevertheless, this journey to full citizenship was complicated by additional hurdles for the women. Patriarchal racism, according to Bolzenius, perceived black women as sexually promiscuous, unintelligent and at best suited to menial tasks. The WAC offered black women the opportunity to craft a new identity based on patriotism and military service. In this

10 Corinna Peniston-Bird, "Of Hockey Sticks and Sten Guns: British Auxiliaries and Their Weapons in the Second World War", Women's History Magazine 76 (2014): 13-22, Gerard J. DeGroot, "Whose Finger on the Trigger? Mixed Anti-Aircraft Batteries and the Female Combat Taboo", War in History 4 (4) (1997): 434-453, Gerard J. DeGroot, "I Love the Scent of Cordite in Your Hair': Gender Dynamics in Mixed Anti-Aircraft Batteries during the Second World War", History 82 (265) (1997): 73-92, Joshua Goldstein, War and Gender: How Gender Shapes the War System and Vice Versa (Cambridge, 2003), and Jutta Schwarzkopf, "Combatant or Non-Combatant? The Ambiguous Status of Women in British AntiAircraft Batteries during the Second World War", War \& Society 28 (2) (2009): 105-31.

11 Gerard J. DeGroot and C. Peniston-Bird, A Soldier and a Woman: Sexual Integration in the Military (London, 200o), Tessa Stone, "Creating a (Gendered?) Military Identity: The Women's Auxiliary Air Force in Great Britain in the Second World War", Women's History Review 8 (4) (1999): 605-624, Melissa Herbert, Camouflage Isn't Only for Combat: Gender, Sexuality and Women in the Military (New York, 1998), and Nancy Goldman, Female Soldiers - Combatants or Non-Combatants (Ann Arbor, MI, 1982). See also, Cynthia Enloe, Maneuvers: The International Politics of Militarizing Women's Lives (Berkeley, CA, 200o), Linda Grant De Pauw, Battle Cries and Lullabies (Oklahoma, 1998), Julie Wheelright, Amazons and Military Maids (London, 1994), Jeanne Holm, Women in the Military: An Unfinished Revolution (San Francisco, CA, 1992), Jean Bethke Elshtain, Women and War (Chicago, IL, 1987), Cynthia Enloe, Does Khaki Become You? Militarisation in Women's Lives (Boston, MA, 1983). 
insightful article, Bolzenius illustrates the involvement of African American women in the movement for full citizenship that predates the traditional periodization of the post-war Civil Rights movement and the literature that largely privileges the activism of men. Bolzenius's article highlights the activism of African American women and reveals their wartime service that until now has remained largely understudied.

Gender and race also impacted African American military nurses as Charissa Threat has recently revealed. African American women used their femaleness to illustrate their suitability for military nursing. ${ }^{12}$ Thus, as Bolzenius maintains in her article on the WAC, military nursing also became a space for African American women to assert their citizenship. Most of the studies of military nurses do not interrogate race. Rather, they focus on the fact that captured nurses were regarded as non-civilians by the enemy and interned as prisoners of war. We Band of Angels: The Untold Story of the American Women Trapped on Bataan (2013) reveals the experiences of the army nurses who were part of the Bataan death march alongside their soldier brothers. All This Hell: U.S. Nurses Imprisoned by the Japanese (2003) looks at the U.S. army nurses captured and imprisoned by the Japanese during the war in the Pacific. ${ }^{13}$ Studies also illustrate the heroism of military nurses. No Time for Fear: Voices of American Military Nurses in World War II (1997) explores the work and the work conditions of hundreds of army nurses sent to care for troops throughout the globe. And If I Perish: Frontline U.S. Army Nurses in World War II (2004) reveals the working conditions of military nurses through an examination of letters sent to loved ones as the nurses came close to the battle lines. What has received less attention is sexuality and military service. In this special issue, Ravenel Richardson shares the intimate experiences of two U.S. military nurses who became pregnant during their service. Military nurses were not permitted to marry and thus pregnancies were, according to Richardson, deliberately omitted from the official military record and thus largely hidden from history. Richardson's article examines the personal correspondence of two nurses who embarked on romantic relationships that resulted in pregnancy and their

12 Charissa J. Threat, Nursing Civil Rights: Gender and Race in the Army Nurse Corps (Urbana, IL, 2015).

13 See, Elizabeth Norman, We Band of Angels: The Untold Story of the American Women Trapped on Bataan (New York, 2017), Nicole Tyrer, Sisters in Arms: British Army Nurses Tell Their Story (London, 2008), Diane Burke Fessler, No Time for Fear: Voices of American Military Nurses in WWII (East Lansing, MI, 1997), Eric Taylor, Front-line Nurse: British Nurses in WWII (London, 1997), and Barbara Brooks Tomblin, G.I. Nightingales: The Army Nurse Corps in World War II (Lexington, KY, 1996). 
subsequent discharge from the Army. Both women had to navigate social criticism, a loss of profession and economic independence. The article reveals a hidden history of unmarried, pregnant nurses and their experiences during and after the Second World War and expands our understanding of sexuality and intimacy during conflict.

Recent works by Alexis Peri, Anna Krylova, Roger Markwick, Euridice Charon Cardona and others have broadened our understanding of the experiences of Soviet women fighting on the front lines of the Eastern front. ${ }^{14}$ Krylova maintains that Soviet women volunteered en masse in 1941 to fight the Germans when the UsSR was invaded. This was not a sudden decision, claims Krylova, but one that was crafted throughout the 1930s as women thought of themselves as soldiers. Thus, Krylova suggests, gender identity has greater complexity even in a patriarchal totalitarian regime. At the same time that the government encouraged Soviet women to join the military as combatants, Polish women were refused admission to the military as combatants. When the Polish Army in the Soviet Union formed in 1942, Polish women could join only as auxiliaries. Nevertheless, as Anna Marcinkiewicz-Kaczmarczyk argues in this special issue, the army provided Polish women held in the Soviet Union in labour camps and prisons a way to escape, albeit not on the same terms as male prisoners. Additionally, while Polish women suffered the same deprivations as their male peers in the army, they were expected to care for the men and provide psychological and physical support whilst receiving no such care themselves. Thus, gender expectations had severe physical and psychological ramifications for Polish women in the military. Eventually this was acknowledged, and a rest camp was established for the women.

This special issue of the $I J M H$ adds to the literature to illustrate the way that gender, race, and marital status impacted the way women experienced the Second World War. Together, these articles reveal that women were conscious actors who made decisions to fight for survival, for civil rights and for participation in the war. Many of those decisions had long-term impacts. Military nurses made decisions and choices about romantic relationships that had

14 Alexis Peri, "Womanhood Under Fire: Gender Practice and Identity in Soviet Accounts of the Front Lines", in Women's Experiences of War: Exile, Occupation and Everyday Life, 193945, eds. Mark Crowley and Sandra Trudgen Dawson (London, forthcoming in 2020), Youri Obraztsov, Soviet Women Snipers of the Second World War (Paris, 2014), Zoya Matveyevna, Smirnova-Medvedeva and Kazimiera J. Cottam, On the Road to Stalingrad: Memoirs of a Woman Machine Gunner (Sydney, 1997), Anna Krylova, Soviet Women in Combat: A History of Violence on the Eastern Front (Cambridge, 2010), 168-169; Roger D. Markwick and Euridice Charon Cardona, Soviet Women on the Frontline in the Second World War (New York, 2012). 
consequences - pregnancy and immediate discharge from the military. The wives of spies had choices too. They could compromise the status of their spouse or they could maintain secrecy. African American women chose to use their military status as wACs to assert full citizenship in a nation that claimed they were unfit for that citizenship. Polish women used the army as a vehicle to escape the labour camps in the Soviet Union and to fight for their nation's independence. In the end, this meant choosing exile or a return to a Sovietcontrolled Poland.

What emerges from these studies is the breadth of scholarship on women's experiences of the Second World War. The articles illustrate some of the hidden roles and choices women made during the conflict, as well as the longterm impact of their actions. This special issue of the $I J M H$ seeks to add to the literature while at the same time acknowledging that the articles do not demonstrate the entire breadth of women's experiences of total war. Nevertheless, the issue does highlight some and contributes to the debate on women and the Second World War - a conflict that continues to reveal new directions for future research. Thus, the hope is that this special issue will provide fertile ground for future studies of women and war.

\section{Bibliography}

Baldoli, Claudia, ed. Bombing, States and Peoples in Western Europe 1940-1945 (London: Bloomsbury Publishing, 2011).

Batinić, Jelena. Women and Yugoslav Partisans: A History of World War II Resistance (Cambridge: Cambridge University Press, 2015).

Bethke Elshtain, Jean. Women and War (Chicago, IL: University of Chicago Press, 1987).

Brooks Tomblin, Barbara. G.I. Nightingales: The Army Nurse Corps in World War II (Lexington, KY: University Press of Kentucky, 1996).

Burke Fessler, Diane. No Time for Fear: Voices of American Military Nurses in World War II (East Lansing, MI: Michigan State University Press, 1997).

Byfield, Judith, Carolyn Brown, Timothy Parsons, and Ahmad Alawad Sikainga, eds. Africa and World War II (Cambridge: Cambridge University Press, 2015).

Chickering, Roger, Stig Förster, and Bernd Greiner, eds. A World at Total War: Global Conflict and the Politics of Destruction, 1937-1945 (Cambridge University Press, 2005). Cohn, Marthe, with Wendy Holden. Behind Enemy Lines: The True Story of a French Jewish Spy in Nazi Germany (New York: Random House, 2007).

Collingham, Lizzie. The Taste of War: World War II and the Battle for Food (London: Penguin, 2011). 
Crowley Mark J., and Sandra Trudgen Dawson, eds. Home Fronts: Britain and the Empire at War, 1939-45 (London: Boydell \& Brewer 2017).

DeGroot, Gerard J. "Whose Finger on the Trigger? Mixed Anti-Aircraft Batteries and the Female Combat Taboo". War in History 4 (4) (1997), 434-453.

DeGroot, Gerard J. "I Love the Scent of Cordite in Your Hair': Gender Dynamics in Mixed Anti-Aircraft Batteries during the Second World War". History 82 (265) (1997), 73-92.

DeGroot, Gerard J., and Corinna Peniston-Bird. A Soldier and a Woman (London: Longman, 2000).

De Pauw, Linda G. Battle Cries and Lullabies (Oklahoma: University of Oklahoma Press, 1998).

Edgerton, David. Britain's War Machine: Weapons, Resources, and Experts in the Second World War (Oxford: Oxford University Press, 2011).

Enloe, Cynthia. Maneuvers: The International Politics of Militarizing Women's Lives (Berkeley, CA: University of California Press, 2000).

Enloe, Cynthia. Does Khaki Become You? Militarisation in Women's Lives (Boston, MA: South End Press, 1983).

Escott, Beryl. Heroines of soE: Britain's Secret Women in France (Stroud: The History Press, 2010).

Gildea, Robert. Fighters in the Shadows: A New History of the French Resistance (Cambridge, MA: Harvard University Press, 2015).

Goldstein, Joshua. War and Gender: How Gender Shapes the War System and Vice Versa (Cambridge: Cambridge University Press, 2003).

Gobetti, Ada. Partisan Diary: A Woman's Life in the Italian Resistance, trans. Jomarie Alano (Oxford: Oxford University Press, 2014).

Goldman, Nancy. Female Soldiers - Combatants or Non-Combatants (Ann Arbor, MI: University of Michigan Press, 1982).

Grayzel, Susan. At Home and Under Fire: The Air Raid in Britain from the Great War to the Blitz (Cambridge: Cambridge University Press, 2012).

Heer, Hannes, and Klaus Naumann. War of Extermination: The German Military in World War II (New York: Berghahn, 2000).

Herbert, Melissa. Camouflage Isn't Only for Combat: Gender, Sexuality and Women in the Military (New York: New York University Press, 1998).

Higonnet, Margaret, and Patrice Higonnet. "The Double Helix". In Behind the Line: Gender and the Two World Wars, eds. M. Higonnet, Jene Jackson, Sonya Muchel, and Margaret Weitz (New Haven, CT: Yale University Press, 1987).

Holm, Jeanne. Women in the Military: An Unfinished Revolution (San Francisco, CA: Presidio Press, 1992). 
Jackson, Ashley. The British Empire and the Second World War (New York: Continuum, 2006).

Khan, Yasmin. The Raj at War: A People's History of India's Second World War (London: Vintage Digital, 2015).

Krylova, Anna. Soviet Women in Combat: A History of Violence on the Eastern Front (Cambridge: Cambridge University Press, 2011).

Markwick, Roger D., and Euridice Charon Cardona. Soviet Women on the Frontline in the Second World War (London: Palgrave Macmillan, 2012).

Margolis, Rachel. A Partisan from Vilna, trans. F. Jackson Piotrow (Boston, MA: Academic Studies Press, 2010).

Mcintosh, Elizabeth P. Sisterhood of Spies: The Women of the oss (Annapolis, MD: Naval Institute Press, 2009).

Matveyevna, Zoya, Smirnova-Medvedeva, and Kazimiera J. Cottam. On the Road to Stalingrad: Memoirs of a Woman Machine Gunner (Sydney: Nepean, 1997).

Masson, Madeleine. Christine: soe Agent and Churchill's Favourite Spy: A Search for Christine Granville (London: Virago, 2005).

Noakes, Jeremy. The Civilian in War: The Home Front in Europe, Japan and the USA in World War II (Liverpool: Liverpool University Press, 200o).

Norman, Elizabeth. We Band of Angels: The Untold Story of the American Women Trapped on Bataan (New York: Random, 2013).

Obraztsov, Youri. Soviet Women Snipers: of the Second World War (Paris: Histoire and Collections, 2014).

O'Connor, Bernard. soe Heroines: The Special Operations Executive's French Section and Free French Women Agents (Blandford, Dorset: Amberley Press, 2018).

Pattinson, Juliette. Behind Enemy Lines: Gender, Passing and the Special Operations Executive in the Second World War (Manchester: Manchester University Press, 2007).

Pearson, Judith L. The Wolves at the Door: The True Story of America's Greatest Female Spy (New York: Diversion Books, 2014).

Peniston-Bird, Corinna. "Of Hockey Sticks and Sten Guns: British Auxiliaries and Their Weapons in the Second World War". Women's History Magazine 76 (2014), 13-22.

Peri, Alexis. "Womanhood Under Fire: Gender Practice and Identity in Soviet Accounts of the Front Lines". In Women's Experiences of War: Exile, Occupation and Everyday Life, 1939-45, eds. Mark Crowley and Sandra Trudgen Dawson (London, forthcoming in 2020).

Stone, Tessa. "Creating a (Gendered?) Military Identity: The Women's Auxiliary Air Force in Great Britain in the Second World War". Women's History Review 8 (4) (1999), 605-624. 
Schwarzkopf, Jutta. "Combatant or Non-Combatant? The Ambiguous Status of Women in British Anti-Aircraft Batteries during the Second World War". War \& Society 28 (2) (2009), 105-131.

Taylor, Eric. Front-line Nurse: British Nurses in WWII (London: Robert Hale Ltd., 1997). Threat, Charissa J. Nursing Civil Rights: Gender and Race in the Army Nurse Corps (Urbana, IL: University of Illinois Press, 2015).

Tyrer, Nicole. Sisters in Arms: British Army Nurses Tell Their Story (London: Weidenfeld \& Nicolson, 2008).

Wheelright, Julie. Amazons and Military Maids (London: Pandora, 1994). 